\title{
PATENTS AND GENETIC ENGINEERING TECHNOLOGIES: A REVIEW OF JUDICIAL DECISIONS
}

\author{
Sharifa Sayma Rahman*
}

\begin{abstract}
Different classes of people have raised moral objections on a number of times against granting patents on living organisms. There has been a recent focus on patents partly because the corporate world is only concerned with economic returns and the market prospect of a genetic product. The purpose of this article is to revisit the debate on the patent of genetic engineering technologies and provide partial recommendations on rationalising patent protection while mitigating moral arguments. This article re-examines the intellectual property frameworks as well as case laws regarding biological materials in selected countries i.e., Europe, the United States of America, Australia, Malaysia, and under international agreements such as the WTO Agreement on Trade-Related Aspects of Intellectual Property Rights (TRIPS). This article is based on primary as well as secondary materials that have been written on the patent of life forms and genetic research. There is an inconsistency between philosophical principles and the implementation of biotechnology patents due to the existing economic, political, and ideological conditions among countries, along with existing divergences in the field of genetically engineered technologies. Hence, during such circumstances, the most coherent position is to proceed with vigilance as it is not possible to shut down bioindustrialisation. One such vigilant pathway in the presence of contemporary evidence to minimise commercialisation of life science creations. Patents of genetically engineered products should be strictly monitored to fulfil commitment towards international human rights, which is to provide reasonably priced healthcare and medical treatment.
\end{abstract}

Keywords: $\quad$ Patent, life forms, genes, moral arguments, commercialisation.

Assistant Professor, Department of Law, Eastern University Bangladesh. Email: sayma2205@gmail.com. 


\title{
PATEN DAN TEKNOLOGI KEJURUTERAAN GENETIK: SATU SEMAKAN KEPUTUSAN KEHAKIMAN
}

\begin{abstract}
ABSTRAK
Golongan manusia yang berbeza telah membangkitkan beberapa bantahan moral terhadap penganugerahan paten untuk organisma hidup. Terdapat focus terkini terhadap paten sebahagiannya kerana dunia korporat hanya mementingkan pulangan dari segi ekonomi dan prospek pasaran terhadap produk genetik. Tujuan makalah ini adalah untuk melihat semula perbahasan berkaitan paten teknologi kejuruteraan genetik dan menyediakan sebahagian cadangan untuk merasionalisasikan perlindungan paten dalam mengurangkan hujah moral. Makalah ini menilai semula kerangka harta intelektual dan juga kes undang-undang berkaitan dengan bahan biologi di negara terpilih iaitu Eropah, Amerika Syarikat, Australia, Malaysia dan di bawah perjanjian antarabangsa seperti Majlis Persetujuan WTO bagi Aspek Berkaitan PerdaganganUntuk Hak Harta Intelek (TRIPS). Makalah ini adalah berdasarkan bahan dari sumber primer dan sekunder yang ditulis mengenai paten dalam bentuk kehidupan dan kajian genetik. Terdapat ketidakseragaman di antara prinsip falsafah dan perlaksanaan paten bioteknologi kerana keadaan ekonomi, politik, dan ideologi antara negara, beserta dengan perbezaan dalam bidang teknologi kejuruteraan genetik. Maka,dalam keadaan ini, posisi yang paling baik adalah meneruskan dengan penuh waspada kerana adalah tidak mungkin untuk menutup bio-industrilisasi. Kewaspadaan ini akan membawa kepada kehadiran bukti temporari yang boleh mengurangkan pengkomersilan ciptaan sains kehidupan. Paten terhadap produk kejuruteraan genetik seharusnya dikawal dengan lebih ketat untuk memenuhi komitmen terhadap hak asasi manusia antarabangsa iaitu menyediakan penjagaan kesihatan dan rawatan perubatan dengan harga yang berpatutan.
\end{abstract}

Kata kunci: $\quad$ Paten, bentuk kehidupan, gen, hujah moral, pengkomersilan.

\section{INTRODUCTION:}

The fundamental rationale of genetic engineering is to regulate the utility of genes not only to evade metabolic inaccuracies in embryonic organisms but also to generate enhanced organisms. ${ }^{1}$ The rapid

1 Edward Lawrie Tatum, "A case history in biological research," Science 129 (1959): 1711-15. 
advancement of biotechnology and the controversy surrounding the patent of life forms have recently become a focal point in the media. There are moral controversial debates for many genetically modified creatures in recent years; such as human clones, part-human and partanimal creatures. The primary arguments against patenting genetically modified organisms are the inability to protect human dignity, preservation of human life, and creating the concept of ownership over another human. These issues raised a logical question about whether life is susceptible to commercial exploitation. ${ }^{2}$ The corporate world is less concerned about morality and ethics and more concerned about the economic return and market prospective of a particular patented product. ${ }^{3}$ On the other hand, the modern genomic science community is worried that the patenting system will decelerate research at the expense of expensive medical skills.

There is an inconsistency between philosophical principles and implementation of patent biotechnology due to the existing economic, political, and ideological conditions among countries along with crucial divergences present in the field of genetically engineered technologies. As a result, it is high time to revisit the discussion on the patent of genetic engineering technologies. This paper focuses on legal and ethical considerations in the patent of life forms and genetic research. In doing so, this paper re-examines the intellectual property frameworks along with case laws regarding biological materials in selected countries and provides partial recommendations on rationalising patent protection for genetic engineering while mitigating the moral arguments.

\section{PATENT PROTECTION IN BIOTECHNOLOGY AND GENETIC RESEARCH: A COMPARATIVE PERSPECTIVE}

The objective of granting a patent is to encourage the innovator towards new scientific, technological, and industrial advancements. Unless monopoly rights are granted to the inventor, the industrial growth will come to a standstill as there would not be a significant motivation to

2 Accessed April 25, 2020, http://theconversation.com/who-owns-ourgenes-myriad-genetics-monopoly-challenged-13489.

3 Rajeev Singh, "Life Patents: The Answers to the Moral Questions," Social Science Research Network (2012), accessed April 20, 2020, http://ssrn.com/abstract=2109762. 
innovate and design. Patents encourage inventors to disclose their research as early as possible in return for a reward against the innovation. Thus, it helps to enrich the stock of information and ideas which are available for access and use. ${ }^{4}$ It has been observed that biotechnology industries spend more time and money for patent protection than any other trade due to the need to protect lawful expensive innovations. ${ }^{5}$ This is despite several problems associated with the application of patent laws including technical difficulties amidst moral ambiguity.

The developed countries, the United States of America (USA), the European Union (EU), and Australia are the traditional leaders in the area of genetically engineered technologies; while other emergent powers, such as Malaysia also desire to be part of this highly potential sector. ${ }^{6}$ The motivation for the selection of these jurisdictions is that they follow diverse genetic research policies and also have different requirements on exclusion from patentable inventions.

\section{Patentability of biological materials}

In Australia, the Australian Patent Act 1990 expressly prohibits human genes and biological processes from standard patents. Section 18(2) of the Patents Act 1990 states "biological materials including their components and derivatives, whether isolated or purified or not and however made, which are identical or substantially identical to such materials as they exist in nature" are not patentable inventions. Under section 18(3) 'plants and animals, and the biological processes for the generation of plants and animals are also excluded from innovation patents. However, according to section 18(4) exclusion does not apply if the invention is a microbiological process or the product of such a process. Additionally, section 18(5) defines the term 'biological

4 Anne Fitzgerald and Dimitrios Eliades, Intellectual Property Nutshell Series $3^{\text {rd }}$ ed. (Sydney: Thomson Law book Co, 2008), 14.

5 C Roberts, "The Prospects of Success of the National Institute of Health's Human Genome Application," European Intellectual Property Review, no.1 (1994):30.

6 Mohammad Firdaus Bin Abdul Aziz, Michael Morrison \& Jane Kaye, "Regulating human stem cell research and therapy in low- and middleincome countries: Malaysian perspectives" New Genetics and Society,37(1) (2018): 2-20. 
materials' to include 'DNA, RNA, proteins, cells, and fluids,' but it does not describe the words "components and their derivatives" and "substantially identical."

In the case of Fertilitescentrum AB and Luminis Pty Ltd (2004) APO19, Deputy Commissioner Herald stated that the prohibition in section 18(2) clearly covers all biological processes applied from fertilisation to birth so long as the process is indeed one that directly relates to the generation of a human being and the exclusion also includes the processes of generating the entity that can first claim a status of a human being; e.g. processes for fertilising an ovum, cloning at the 4-cell stage by division cloning by replacing nuclear DNA. ${ }^{7}$

The application of Woo-Suk Hwang (2004) APO 24 claimed that ' a method for producing chimera embryos derived by nuclear transfer using human cells as nucleus donors and enucleated bovine oocytes as recipients'. In other words, it seeks to create an embryo where the nuclear DNA is human, and the mitochondrial DNA is bovine. The application was contrary to section 18(2), so it was refused under section 50(1) (a) of the Patents Act 1990. In addition, the Prohibition of Human Cloning Act 2002, section 20(2) makes it an offence to intentionally create a "hybrid embryo," which is defined as "an animal egg into which the nucleus of a human cell has been introduced." 8

The position in the United States- 35 U.S. Code $\S 101$ deals with patentable inventions. It states as follows:

Whoever invents or discovers any new and useful process, machine, manufacture, or composition of matter, or any new and useful improvement thereof, may obtain a patent therefore, subject to the conditions and requirements of this title.

According to the 35 U.S.C. $§ 100(a \&$ b) (2011),

[t]he terms invention means invention or discovery and [t]he terms process means process, art or method, and includes a new use of a known process, machine, manufacture, composition of matter, or material.

Prior to the year 2013, in the United States, biological matters could be eligible for patents if they were adequately 'isolated' from their natural environment. However, in Association for Molecular Pathology $v$.

7 Accessed June 25, 2020, https://jade.io/article/587775.

8 Accessed June 25, 2020, https://jade.io/article/587775. 
Myriad Genetics, Inc., 569 U.S. 576 (2013) the U.S. Supreme Court ruled that naturally occurring gene sequences would be non-patentable inventions.

The EU laws presently grant isolated biological materials as patentable. Article 3 of the Directive 98/44 EC states:

For the purposes of this Directive, inventions which are new, which involve an inventive step, and which are susceptible of industrial application shall be patentable even if they concern a product consisting of or containing biological material or a process by means of which biological material is produced, processed or used.

Biological material which is isolated from its natural environment or produced by means of a technical process may be the subject of an invention even if it previously occurred in nature.

Article 5 of the Directive provides:

the human body, at the various stages of its formation and development, and the simple discovery of one of its elements, including the sequence or partial sequence of a gene, cannot constitute patentable inventions.

An element isolated from the human body or otherwise produced by means of a technical process, including the sequence or partial sequence of a gene, may constitute a patentable invention, even if the structure of that element is identical to that of a natural element.

The industrial application of a sequence or a partial sequence of a gene must be disclosed in the patent application.

Thus, Article 5 mentions the position of the EU regarding the patentability of genes or genetic sequences.

In Malaysia, section 12 of the Patent Act 1983 provides that a patent can be granted to an invention if it is new, involves an inventive step, is industrially applicable, and the innovation maybe related to a product or process. Whereas section 13(1) (b) of the Patent Act 1983 simply states that man-made living microorganisms, microbiological processes, and the product of such processes are patentable. There is no clear mention of the exclusion of nature's handiwork, nevertheless in section 13 (1) (a) of the Act, 'discoveries' is a bar to patentability.

The above discussions make it clear that in the mentioned countries some principles have been followed for patentability of genetic materials. Since isolation of genes without invention of its 
practical application merely represents a discovery; it must be isolated from its naturally occurring state and consequences in an 'artificially created state of affairs' by means of a technical procedure. The function of any original variant should not have been previously identified and need to be specifically explained in the patent application. Furthermore, the tests of innovation, non-obviousness (inventiveness), and utility or industrial application must be fulfilled for patentable human genes or genetic sequences.

\section{Necessities of a Valid Patent}

The Agreement on Trade-Related Aspects of Intellectual Property Rights (TRIPS Agreement) provides three criteria and conditions for an invention to be patentable.

Article 27.1 of the TRIPS Agreement states that: patents shall be available for any inventions, whether products or processes, in all fields of technology, if they are new, involve an inventive step, and are capable of industrial application.

The following requirements of patentability are generally similar across patent systems internationally. They include a full description, patentable subject matter, novelty, inventive step (non-obvious), Industrial applicability, and Exceptions to Patentability.

Under the full description requirement, the patent specification should give details of the invention, including the best manner known to the applicant for performing the innovation. The reason for this proviso is that the reader of the specification must have adequate information to replicate the invention. This condition primarily resulted in complexities for biotechnological inventions, because by simply explaining a living organism is not enough for its reproduction.

\section{Patentable Subject Matter}

In patent law, there are distinctions between discoveries and inventions. Patent cannot be granted for discovery of an entity which already exists in nature. In the application of biotechnological research, the difference between discoveries and inventions has significant complexities. For example, sequencing of the human genome is the identification of molecular entities which exist in the human body in a 
natural state. Therefore, this can be termed as discovery and does not qualify as a patentable invention. However, the International Patent Office tries to draw a distinction between entities existing in nature, which are termed as discoveries. On the other hand, the process which separates the natural entities from nature is termed a patentable invention. In addition, a substance will be patentable if it is novel, inventive and the same has not existed before. ${ }^{9}$

The third requirement is a novelty. The question of novelty comes where the effects of suggested genetic research are identical to existing research, or if the results are the invention of known techniques to recognise a matter naturally happening. ${ }^{10}$

The fourth is known as the inventive step (non-obvious). In the area of biotechnology, questions of obviousness arise when known technology is used to produce known and commercially attractive products, e.g., production of known protein using recombinant DNA. ${ }^{11}$

Industrial applicability (useful) is the fifth requirement. The utility is one of the difficulties which arise in patents for biotechnology, especially for patents regarding human DNA, where most of the genetic research is related to isolating and identifying gene sequences and DNA fragments. It is also reflected in the works of the Human Genome Project which were set up in 1988 for the function of mapping and sequencing the human genome. ${ }^{12}$

Another case study explores patent application in Europe where the requirement is the disclosure on how the invention will meet the criterion of industrial applicability. For example, in the case of Eli Lilly $v$ Human Genome Science, ${ }^{13}$ Eli Lilly challenged the validity of a patent which was claimed by Human Genome Science relating to the

9 G Dworkin, "Should there be property rights in genes?" Philosophical Transactions of The Royal Society B: Biological Science 352, no.1357 (1997): 1077-1080, accessed April 20, 2020, https://doi.org/10.1098/rstb.1997.0088.

$10 \mathrm{~J}$ McKeough and A Stewart, Intellectual Property in Australia $2^{\text {nd }}$ ed. (Sydney: Butterworths, 1997), 338-339.

11 Ibid., 340.

12 Accessed April 19, 2020, http://www.nhgri.nih.gov/HGP/ and http://www.oml.gov/.

13 Eli Lilly and Company v Human Genome Sciences Inc, EWCA Civ 33 (2010). 
protein neutrokine- $\infty$ and antibodies to the protein. It was held that merely allocating neutrokine- $\infty$ to a known family of proteins was not enough because it could not meet the criterion of industrial applicability. ${ }^{14}$

The next requirement is the exceptions to patentability. Recently, exceptions to patentability have become the most important topic due to the related moral and ethical issues.

Article 27 of the TRIPS agreement deals with the patentable subject matter. Key to the discussion is article 27.1 of TRIPS which provides that-

.... patents shall be available for any inventions, whether products or processes, in all fields of technology, provided that they are new, involve an inventive step and are capable of industrial application....

Article 27.2 on the other hand envisages that certain inventions can be excluded by the Members of WTO from patentability in order to protect:

... order public or morality, including to protect human, animal or plant life or health or to avoid serious prejudice to the environment...

In this regard, article 27.3.b permits members to exclude from patentability:

...plants and animals other than microorganisms, and essentially biological processes for the production of plants or animals other than non-biological processes for the production of plants or animals other than non-biological or microbiological processes.

The TRIPS agreement enables the member countries to exclude inventions from patentability if these are against morality or ordre public. ${ }^{15}$ However, this exclusion cannot be made merely on the ground that the inventions are prohibited by the law of the member country. It must ensure that the inventions damage the morality of society, but the term 'morality' is not clearly defined. This is due to the flexibility in taking decisions on the scope of patentable inventions in different jurisdictions. Therefore, the patentable subject matter is expanding by the legislation of countries and by the decisions of their national courts.

14 Ibid., 157.

15 Article 27(2) of Agreement on Trade-Related Aspects of Intellectual Property Rights 1994 (TRIPS Agreement). 
During the TRIPS negotiations, the ethical question of granting patent monopoly rights for living things and genetic material was a controversial issue. This debate has gradually increased through the expansion in genetic research. For example, the Human Genome Project as well as issues relating to the development of biotechnology industries and the question of ownership of human tissue have been raised in the case of Moore $v$ Regents of the University of California (1988). ${ }^{16}$

\section{PUTTING A FACE ON GENES PATENT LITIGATION}

Recently, the differences between discoveries and inventions regarding biotechnology have been considered in many cases. In this connection, the case of Diamond $v$ Chakrabarty ${ }^{17}$ which relates to genetically engineered bacteria that break down the elements of crude oil has established the principle in the United States. The patent application, in this case, was refused on the ground that the bacteria are living organisms and a product of nature. When the applicant went to the Supreme Court of the United States, the previous decision was rejected, and it was held that "anything under the sun that is made by man"18 is patentable and the distinction is not between living and inanimate objects, but between the products of nature, whether living or not and human-made inventions. ${ }^{19}$

According to Burger CJ:

Judged in this light, the respondent's microorganism plainly qualifies as patentable subject matter. His claim is to non-naturally occurring manufacture or composition of matter - a product of human ingenuity.

Thus, in this case the phase of patenting living things in the field of genetic engineering was firstly commenced through genetic modifications of microorganisms, which persisted to be patentable all over the United States. Consecutively, this has led to amplified

\footnotetext{
16 Moore v Regents of the University of California 249m Cal Rptr 494, Court of Appeals, (1988); 271 Cal Rptr 146, California Supreme Court, (1990).

17 Diamond v Chakrabarty 447 US 303, 100 S Ct 2204, 65 L Ed 2d 144, USSC, (1980).

18 Diamond v Chakrabarty 447 US 303, 100 S Ct 2204, 65 L Ed 2d 144, USSC (1980): 150.

19 Ibid., 152.
} 
protection of plant variety inventions and other life science innovations across the world.

The same concern was raised in 1988 regarding the Oncomouse, the transgenic animal, which was basically a mouse specially bred to create cancer. Subsequently, it was decided that genetic engineering technologies used to establish transgenic animals carrying an activated oncogene sequence can be patentable. Hence, the US patent was granted to Harvard University for this innovation in the same year. ${ }^{20}$

In the Howard Florey/Relaxin ${ }^{21}$ case, the distinction between discoveries and inventions in respect of biotechnology took place; where a patent was granted for the nucleotide sequence for the protein known as Relaxin. This protein is produced during human pregnancy and helps in relaxing the uterus at the time of childbirth. There were oppositions for this on several grounds. One concern was that patenting human genes means patenting human life. ${ }^{22}$ The major argument was that the gene encoding Relaxin was always present in the human body, hence it was only a discovery rather than invention. On the other hand, the opposite argument was that the isolated Relaxin gene was developed as the result of technical activity, thus the innovation was new and fulfilled the requirement of having an inventive step in the development process. Hence, the European Patent Office (EPO) declined the arguments against granting a patent and decided that the technical endeavour in separating the gene constituted an invention as per EPO Guidelines. ${ }^{23}$

In Kirin-Amgen Incorporated $v$ Board of Regents or the University of Washington and Genetics Institute, Inc3 (1995) 33 IPR 557, the Commissioner of Patents in Australia held that purified or isolated DNA sequence encoding the human protein erythropoietin was 'an artificially created state of affairs'. Thus, 'purified and isolated' DNA sequences were patentable.

20 US Patent No. 4,736,866.

21 EPOR 541(1995).

22 Ibid.

23 Guidelines for Examination in the European Patent Office; G Dworkin, "Should there be property rights in genes?" Philosophical Transactions of The Royal Society B: Biological Science 352, no.1357 (1997): $1077-$ 1080, accessed April 20, 2020, https://doi.org/10.1098/rstb.1997.0088. 
In the Kingdom of the Netherlands $v$. Council of the European Union (2001) which relates to Article 5 of the Directive 98/44 EC, the court highlighted that the application on the sequence or partial sequence of a human gene must describe in detail the original method of sequencing that led to the invention. It must also explain the industrial application to which the work is to lead. Lacking an application in that form would not be patent-eligible because it would merely be the discovery of a DNA sequence but not an act of invention.

The patenting of natural products and processes has been revised noticeably through the decision of the US Supreme Court in the case of Association for Molecular Pathology v. Myriad Genetics Inc. 569 U.S. 576. The case relates to the validity of patents for disposing genes relating to human breast and ovarian cancer which was challenged. ${ }^{24}$ In 2010, Judge Robert W. Sweet in the US District Court for the Southern District of New York declared that patents on the BRCA1 (part of DNA on chromosome 17) and BRCA2 (part of DNA on chromosome 13) genes were invalid as these were the product of nature because the DNA's structure was not modified, it simply isolated genes from the DNA. In his view, organisms used during discovery are found in nature and the gene encoding the particular protein is located within the human body. ${ }^{25}$ Furthermore, patents related to BRCA 1 and 2 genes also infringed $\S 101$ of the Patent Act as they were in contravention of learning, thinking and transmitting genetic information. ${ }^{26}$ It was also diagnostically determined that both cDNA and gDNA were not patentable. This is because switching off non-coding regions did not alter the basic nature hence altering the growth rate of cells could not be considered a scientific technique. ${ }^{27}$

Conversely, in 2011 the Federal Circuit Court sustained the decision of the District Court partially and overruled the rest. ${ }^{28}$ In 2012, the Federal Court of Appeals also upheld the decision of the Federal Circuit Court ruling that the isolated genes occurring in the nucleotide

24 Association for Molecular Pathology \& Ors v United States Patent and TradeMarks Office \& Myriad Genetics S.D.N.Y. 702 F. Supp. 2d (2010):181.

25 Ibid., 229.

26 Ibid., 236.

27 Ibid., 237.

28 Ass'n for Molecular Pathology v. U.S. Patent \& Trademark Office Fed. Cir. 653 F.3d (2011): 1329, 1356-57. 
sequence, which is not present alone in nature, can be a patentable subject matter. ${ }^{29}$ Similarly, the methods of cancer screening have been held patentable since it comprises the growing cells as well as resolve their growth rate. ${ }^{30}$ In contrast, Myriad's diagnostic assertion is patent ineligible.

The application for certiorari quoted that a large number of patients request genetic testing to identify whether they have mutations in their genes that are correlated to a drastically increased threat of breast $^{31}$ or ovarian ${ }^{32}$ cancer. The respondent acquired patents on two human genes that were associated with this peril, identified as BRCA1 and BRCA2. The applicants were medical experts who chronically examined human genes with genetic testing procedures, but they were forbidden from scanning the genes that Myriad Genetics allegedly owned. Meanwhile, several civil rights groups argued that the patentable subjects of Myriad Genetics are products of nature and by getting the patent, Myriad obtained monopoly rights over genetic testing, thus hampering future research on these products. On the other side, Myriad argued that a huge investment went behind the invention and the principle of the patent system is to protect the investment, so they claimed exclusive rights to exploit the invention in the UA. At the same time many other questions arose, such as if Myriad could patent genes, it could patent all parts of the human body e.g., cells, liver, and kidney.

The US Supreme Court agreed with the writ of certiorari solely on a particular question: Are human genes patentable? $?^{33}$ The Court also focused on the difference between natural as well as an artificial creation. Justice Thomas conveyed the majority opinion in June 2013 and the Court held that according to $\S 101$ of the Patent Act, isolated gDNA (genomic DNA) was patent-ineligible because substances merely isolated from nature are not capable of being an invention. In

\footnotetext{
29 Ibid., 1351.

30 Ibid., 1358-59.

31 Accessed June 10, 2020, http://www.cancer.org/cancer/breastcancer/ moreinformation/breastcancerearlydetection/breast-cancer-earlydetection-pdf.

32 Accessed June 10, 2020, http://www.cancer.org/cancer/ovariancancer/ detailed guide/ovarian-cancer-pdf23.

33 Association for Molecular Pathology v. Myriad Genetics 133 S. Ct. 694, 184 L. Ed. 2d 496.
} 
addition, a DNA segment found in nature is mere discovery and consequently, gDNA does not satisfy the criteria of patentable subject matter. On the other hand, the cDNA (complementary DNA) which is synthesised and cannot be found naturally is eligible to be patented. ${ }^{34}$

A few years later, a non-profit association, 'Cancer Voices Australia' brought the proceedings against Myriad firm. In the case Cancer Voices Australia v Myriad Genetics Inc [2013]FCA 65, Justice Nicholas mainly focused on the question of whether 'an isolated nucleic acid (with precisely the same chemical composition and structure as that found in the cells of some human beings) is patentable subject matter according to the Patents Act 1990 (Cth)?'

Myriad Genetics argued that 'its patent relating to isolated DNA and RNA, extracted from cells removed from the human body and purged of other biological material with which it is associated in the cell' had fulfilled the essential elements of an 'invention' under section 18(1) (a) of the Patents Act (1990) stating that an invention must be a 'manner of manufacture.' On the other hand, the argument of Cancer Voices Australia was that 'there is no significant or material distinction between nucleic acid in its natural and isolated states. ${ }^{35}$

The case did not highlight the process of diagnosis but concentrated on the composition claims. In addition, the petitioner mainly challenged the validity of Myriad's claims on the ground of invention under section 18 (1) (a) of the Patents Act 1990 and did not make the arguments on any other rationale of invalidity such as 'lack of innovation' and 'short of utility.' 36

Justice Nicholas cited the general principles of patentable subject matter which had been laid down in the case of National Research Development Corp (NRDC) under section 18 of the Patents Act 1990 (Cth) and section 6 Statute of Monopolies 1623. ${ }^{37}$ The High Court of Australia held that the term, 'manner of manufacture' is a dynamic concept, which has evolved over time and the term is not to be literally interpreted since its principles have to be explained broadly

\footnotetext{
34 Ibid., 2111.

35 Accessed April 25, 2020, http://theconversation.com/who-owns-ourgenes-myriad-genetics-monopoly-challenged-13489.

36 Cancer Voices Australia v Myriad Genetics Inc FCA 65, (2013): 8.

37 Ibid., 103.
} 
and flexibly. ${ }^{38}$ It was also noted that technological developments and inventions are excitingly unpredictable. The concept of patentability must be related to economic significance; meaning that its value to the country must be in the field of economic endeavour and must have 'an industrial, commercial or trading character ${ }^{39}$ and not to be mere discoveries, ideas, scientific theories, and laws of nature.

Ultimately the Federal Court of Australia rejected the challenge regarding the validity of one Myriad's patent. Nicholas J granted Myriad's claims while stating three reasons why isolated nucleic acids are patentable subject matter. The words 'manner of manufacture' must not be expressed solely in literal interpretation and it is necessary for patents to keep up with the pace of industrial and technological developments. ${ }^{40}$ The NDRC case law accentuated the 'manner of manufacture' as a broad scope of patentable subject matter; ${ }^{41}$ an "isolated" nucleic acid does not occur naturally, it's an 'artificial state of affairs' created by human intervention; ${ }^{42}$ and the isolation of a particular microorganism may require immense research as well as intellectual effort to be practically useful or economically significant. Thus, these three reasons deemed that the innovation by Myriad Genetics would be patentable. ${ }^{43}$ In early September 2014 on appeal, the Full Court of the Federal Court of Australia unanimously affirmed the judgment of Justice Nicholas. ${ }^{44}$

Afterward, the High Court of Australia approved a special leave to appeal, filed by Yvonne D'Arcy, and mainly re-assessed the benchmark decision in NRDC; that impacted the earlier verdict of the Federal Court of Australia. ${ }^{45}$ In D'Arcy v. Myriad Genetics Inc (2015), the High Court essentially verified the appropriate extent in regards to

38 National Research Development Corp v Commissioner of Patents 102 CLR (1959): 252, 269.

39 Ibid., 271.

40 Ibid., 252, 269; quoted with emphasis in Cancer Voices Australia v Myriad Genetics Inc FCA 65, (2013): 84.

41 Ibid, 107.

42 Ibid, 108.

43 Ibid., 109.

44 D'Arcy $v$ Myriad Genetics Inc Federal Court of Australia, Case NSD359/2013, accessed March 12, 2020, https://www.comcourts.gov.au/file/Federal/P/ NSD359/2013/actions.

45 D’Arcy v. Myriad Genetics Inc HCA 35, (2015): 28. 
'manner of manufacture' and in this connection, the court assessed whether the alleged isolated genes created an "artificial state of affairs" that had economic utility. The majority decision agreed that Myriad's claims did not meet the mentioned requirements of patentable subject matter and argued that isolated nucleotide sequences may be chemically different from natural DNA but their coding genetic materials already exist in the human body. The court ruled that Myriad basically located and sequenced DNA and RNA; so, it is a naturally occurring gene. Besides, man-made genes were assembled to reproduce natural genetic information. ${ }^{46}$ Therefore, the High Court held that Myriad's claims are patent-ineligible subject matters. They also considered other relevant issues such as granting Myriad monopoly protection, it could have alarming effects on novelty by means of infringement without being alert to that fact. ${ }^{47}$

\section{MORALITY EXCLUSIONS UNDER DIFFERENT PATENT LAWS}

In the US, patent laws do not include any exclusion from patentability on the grounds of morality or public order. There is also no bar on patenting for the utilisation and devastation of the human embryo. The US Patent and Trademark Office (USPTO) has usually observed the decision regarding patentability following the case of Diamond $v$ Chakrabarty. ${ }^{48}$ Moreover, patents related to biotechnology and life forms are permitted frequently in the US.

Similarly, the Australian regulation provides no statutory exclusion from patentability on the grounds of public order or morality. In practice, the Australian Patent Office follows the same guideline as to the USPTO after the decision of Diamond $v$ Chakrabarty. Nevertheless, ethical concerns will arise relating to the utility which has already commenced in the United States.

On the contrary, the European regulation such as Section 1(3) provides "A patent shall not be granted for an invention the commercial

\footnotetext{
46 Ibid., 89.

47 Ibid., 93.

48 Diamond v Chakrabarty 447 US 303, 100 S Ct 2204, 65 L Ed 2d 144, USSC, (1980).
} 
exploitation of which would be contrary to public policy or morality."49 The European Patent Office Guidelines were very liberal in respect of morality and "public order," with it being used only in extreme cases. However, recently the same provision of Article 53(a) of the European Patent Convention was used to decline the patent of life and genetic material on ethical grounds. The debate first arose in the case of Harvard's Oncomouse, ${ }^{50}$ the mouse specially bred to develop cancer. The patent was granted on the ground that it had more benefit than harm to human life and the question of morality was decided thereby. The possibility of curing cancer outweighed the hazardous effect on the environment, though the final decision is yet to be made.

According to section 31(1) of the Patent Act 1983 Malaysia, 'The grant of a patent shall not be refused, and a patent shall not be invalidated on the ground that the performance of any act in respect of the claimed invention is prohibited by any law or regulation, except where the performance of that act would be contrary to public order or morality.

As a developing country, Malaysia also forecasts latent medical and financial profits that the biotechnology industry could provide. Therefore, the 2005 National Biotechnology Policy has proclaimed Malaysia's target to become a regional centre in biotech engineering skills. Consequently, the Malaysian Biotechnology Corporation was established to serve as a one-stop institute to assist companies in the biotechnology industry, administer government strategies, and inspire $\mathrm{R} \& \mathrm{D}$ as well as commercialisation. ${ }^{51}$ In 2006, the Malaysian Ministry of Health (MOH) issued the National Guidelines for Stem Cell Research and Therapy. The revised 2009 Guidelines set out other ethical requirements; all research activities involving stem cells

49 Section 1(3), The Patents Act 1977 (Chapter 37, as amended by the Tribunals, Courts and Enforcement Act 2007), accessed April 20, 2020, http://www.wipo.int/wipolex/en/text.jsp?file_id=330537.

50 US Patent No. 4,736,866.

51 Vasodavan, Kalidasan and Kumitaa Theva Das,"Is Malaysia ready for human gene editing: A regulatory, biosafety and biosecurity perspective," Frontiers in Bioengineering and Biotechnology 9 (2021): 171. 
derived from humans or animals must be revised by an institutional ethics body. ${ }^{52}$

\section{UNIVERSAL ARGUMENTS AROUND THE PATENTING OF GENETIC MATERIALS}

One of the most general objections against the patent of life forms is that genetic alteration of life forms is immoral. By authorising patents, it leads to the ownership and commercialisation of life, and decreases life forms to 'products of manufacture.' Furthermore, a country's natural resources may be unlawfully used by allowing patents for certain life forms. Thus, this leads to the expansion and subsequent exploitation of these inventions, which affect humans, animals, and the environment. A group of religious leaders raised objections over the patent of life as they believe humans and animals are creations of God; hence they cannot be patented as human inventions. ${ }^{53}$ Under the Blue Mountain Declaration, document patent of biotechnologies is against the public interest because corporate bodies have no right to ownership of genes.

There are several ethical issues related to the patent of life forms. One of the arguments concentrates on the consequences of the patent and the remaining arguments are based on religious, spiritual, philosophical, or metaphysical stances. There is also a vague objection that patent per se would significantly change the manner of using life forms. However, the consequences of the patent cannot be resolved by suitable regulations or statutes but by modification of the patent law. Other objections, specifically those of philosophical, religious, and spiritual perspectives require more evidence. ${ }^{54}$

Any argument on the basis of morality and patentability of subject matter has a reflection on the ongoing debate between law and morality. According to the positivist school of law, morality must be separated from law and instead derived from the logical as well as

52 Ibid.

53 Richard Stone, "Religious leaders oppose patenting genes and animals," Science 268 (1995): 1126.

54 Kevin W. O'Connor, "Patents for Genetically Modified Animals," journal of Animal Science, no. 7 (1993): 134-40, accessed April 18, 2020, http://jas.fass.org/content/71/suppl_3/34.full.pdf. 
reasonable rules. In contrast, under the school of natural law, rational rules must not be the only basis of law but also needs to reflect morality. ${ }^{55}$ As per the positivist school, if an invention fulfils the patentability qualification it should be granted a patent. On the other hand, the natural school holds the opposite composition. They argue that law is the reflection of morality. So, if an invention violates morality, it will not be granted patent though it fulfils the qualification of patentability.

There are opposite arguments on the patent of life, especially of human genetic material, which creates property rights over human beings. Gene patenting only creates ownership over the invention of analysing, sequencing, manipulating or manufacturing human genes. It only gives ownership over the process of making or manipulating a part of the human body which obviously does not create ownership of a person. It is argued that if patent of technology for transplanting bone marrow is morally acceptable, then why should patent of human genetic technology not be ${ }^{56}$ Ethical, moral, and safety issues regarding biotechnology research are the main concerns of the opponents for granting the patent, but the issues of allowance of the patent for a human being are not important to them. ${ }^{57}$ In most of the cases opposing the patent of genes, there is a misunderstanding on the concept of the nature of patent. The patent does not give the patent holder any right over the human body, but only excludes the third party from exploiting the same innovation relating to the human body. ${ }^{58}$

It is clear that genetic patents and the commercialisation of genetic research will face more controversy regarding morality in the

55 P.J. Fitzgerald, Salmond on Jurisprudence, $12^{\text {th }}$ ed. (London: Sweet \& Maxwell, 1966).

56 David B. Resnik, "The Morality of Human Gene Patents," Kennedy Institute of Ethics Journal, no.71 (1997): 43-61.

57 Shelley A. Rowland \& James W. Piper, "Patents and Biotechnology: Issues around the Patenting of Life Forms," Pipers accessed April 17, 2020,

http://www.piperpat.com/LinkClick.aspx?link=articles/patents/BiotechB asics.pdf.

58 G Dworkin, "Should there be property rights in genes?" Philosophical Transactions of The Royal Society B: Biological Science 352, no.1357
(1997):1081,
accessed
April
20 ,
2020 , https://doi.org/10.1098/rstb.1997.0088. 
future. However, it is also noticeable that the patent system is not well equipped to deal with this controversy leading to growing concerns. The main object of the patent system is to give incentives to the inventor for a certain period. These incentives persuade innovation, thus assuring the quality of human life and society at large. So, the effectiveness will be seriously hampered if unnecessary delays occur due to the debate. Therefore, the disagreements on commercialisation of genetic research should be considered outside the patent system. Other forms of financial support such as awards, allowances, advance market commitments, or equity-based schemes can also motivate inventors. ${ }^{59}$ However to be effective; the alternate methods should not only assure avoidance of controversy but must satisfy commercial effectuality as well. Conversely, genetic engineering technologies are highly profitable businesses, so when the substitute system provides fewer incentives than the existing patent system, it will not be acceptable to the biotechnology industry. ${ }^{60}$

According to article 7 of ICCPR, 'No one shall be subjected to torture or to cruel, inhuman or degrading treatment or punishment. In particular, no one shall be subjected without his free consent to medical or scientific experimentation. ${ }^{61}$

But the current international legal framework is still too ambiguous to protect the rights of researchers. Hence, there is the need for identification of the present legal and operational lacuna as well as the development of legislative and policy frameworks. It will ensure the harmonisation of biomedical research ethics. The Human Genome Organization (HGO) has confirmed that all sequences of patented genetic products and processes must be in the public domain. This will enable the utilisation of the information for utmost research opportunities and publication and assemblage of genomic sequences as

59 Thomas Pogge, Matthew Rimmer and Kim Rubenstein, Incentives for Global Public Health: Patent Law and Access to Essential Medicines (Cambridge: Cambridge University Press, 2010), 133-283.

60 Anna Kingsbury, "Patenting "Life": Human Genetics, Ethics and Patent Law," in Yearbook of New Zealand Jurisprudence, ed.Jacquelin Mackinnon (New Zealand: Waikato University School of Law, 1999), 112-113.

61 International Covenant on Civil and Political Rights 1966, accessed March 13 , 2020 http://www.ohchr.org/en/professionalinterest/pages/ccpr.aspx. 
soon as possible. The World Health Organisation has established the International Clinical Trials Registry Platform that circulates information on clinical trials on a publicly accessible website. In addition, it has also launched an opportunity to set up an environment of transparency in research involving human beings. ${ }^{62}$ Hence, the clinical trials on human beings make sure that the research contributor is competent enough to realise the process along with the effect of exploration and has also the right to withdraw from the research. Furthermore, the ethics board can observe the recognised modus operandi and if any inaccuracy occurs, the authority has to pay reparation to volunteers including the necessary post-care system. ${ }^{63}$

The least developed and developing countries usually provide the resources for genetic harvesting. Unfortunately, there is the exploitation of monopoly rights over life forms and associated inventions which is a crucial subject of apprehension. ${ }^{64}$ With the pace of globalisation of gene research, third world nations will possibly become money-spinning targets for clinical trials, where the informed consent's etiquette will be disregarded. As a result, clinical trials as currently practiced have turned into profitable businesses for sponsoring countries. ${ }^{65}$ Although the intellectual property laws provide monopoly rights over the usage and diffusion of biotechnology for a certain period, private actors and business enterprises seek to protect their innovations with patents in order to counterbalance their costs for invention. However, innovative firms or individuals claim high charges as they have invested heavily into $\mathrm{R} \& \mathrm{D}$, which are usually beyond the affordability of the least developed countries (LDCs) and their governments. There is high-level exploitation in the bioethics regulation and policy from both private and public organisations in dealing with the LDCs. Consequently, litigious questions have arisen on the extent of legislative balance between legality and morality in genetic research. The inclusion or exclusion in the patent of life

\footnotetext{
62 Accessed May 11, 2020, https://www.who.int/ictrp/en/.

63 Arif Jamil, "Patent Framework for the Human Stem Cells in Europe and the USA: Innovation, Ethics and Access to Therapy" (PhD diss., University of Bologna, 2016),57-59.

64 Mead Aroha, "Genealogy, Sacredness, and the Commodities Market," Cultural Survival Quarterly 20, no.2 (1996): 46-53.

65 Marcia Angell, "The Ethics of Clinical Research in the Third World," The New England Journal 337, no.12 (1997): 847-849.
} 
sciences innovations is not always a moral issue, but to a certain extent depends on policy coordination. ${ }^{66}$ Bioethics is an expectation of a symmetric approach among science, moral values, and law. In this situation, the judiciary may act as a moderator. Scientific institutions must scrutinise the uppermost principles of moral and human rights, non-discrimination, egalitarianism along well-versed consent ${ }^{67}$ in the patent process. They should also consider Article 25(1) of the Universal Declaration of Human Rights (1948) which declares that every person has "the right to a standard of living adequate for the health and well-being of himself [or herself] and of his [or her] family, including food, clothing, housing, and medical care and necessary social services."

The international human rights conventions have not yet signified the principles for the protection of interests in intellectual inventions. ${ }^{68}$ It is therefore vital that countries must strive to maintain an appropriate balance between public domain and private monopolies. Reviewers have also put emphasis on the necessity to ensure fair and equitable distribution of benefits derived from utilisation of genes.

\section{CONCLUSION}

Intellectual property law primarily grants exclusive rights to the inventor as encouragement and it also excludes the free rider who might misappropriate the effort and venture capital of the titleholder. However, substantial criticism has risen during the application of patent law for inventions in association with life forms. The criticism has been intense with more life patents sought. This problem does not

66 Paul Root Wolpe and Glenn McGee, "Expert Bioethics as Professional Discourse: The Case of Stem Cells," in Pragmatic Bioethics, ed. Glenn McGee (USA: The MIT Press, 2003), 181-92.

67 Paul Hunt, "Special Rapporteur on the Right of Everyone to the Enjoyment of the Highest Attainable Standard of Physical and Mental Health, Interim Rep. on the Right to Health," U.N. Doc. A/63/263, (2008): 6-12, accessed June 20, 2020, http://daccess-ddsny.un.org/doc/UNDOC/G EN/N08/456/47/PDF/N0845647.pdf?

68 U.N. Econ. \& Soc. Council, Comm. on Econ., Soc. \& Cultural Rights, General Comment No. 17: U.N. Doc. E/C.12/GC/17 (2006) accessed June 22, 2020, http://www.unhcr.org/refworld/category, LEGAL, CESCR,441543594, 0.html. 
belong to the patent realm but when moral and ethical issues are amalgamated with the patent method, the debate regarding genetic engineering comes to light. Ethical norms generally cope with social rights and wrongs but they may change over time along with technology developments and varying moral principles from state to state. In the context of the above discussion under the jurisdictions of the selected countries, it is common that purified or isolated microorganisms or genes are patentable. The inventive step of claims directed to the gene is recognised in Australia, the US, EU, and Malaysia but the methodologies for evaluating inventive steps are not identical. Biotech inventions which go against public interest or morality are not patent-eligible in the EU and Malaysia. This position corresponds to the provision in Article 27.2 of the TRIPS. On the other hand, there is no such morality concern under the US and Australian patent law systems. The US has probably placed the most generous patenting strategies on genetic research, while the EU has adopted a moratorium on the issuance of a patent of a gene. Australia has tried to establish an intermediate, more balanced patent process that grants gene patents to some extent. Currently, the practice in Malaysia is perhaps the most challenging in the aspects of morality, owing to the multi-cultural environment.

In the case of gene patents, the provisions 'public ordre and morality' require equilibrium and uniformity because the recurring national divergences can cause inconsistency among countries.

Therefore, a harmonisation approach of ethical parameters may resolve this debate. Since many counties have different constitutional and legal orders, so divergent sets of legal practices are likely to continue. Biotechnologies that affect moral principles need not be granted, but when the life forms invention has high degrees of utility providing potential service to civilisation, then the patent request must not be rejected on the ground of ethics contemplation. Genetic inventions exhibiting lower adverse effects can be granted, but if the results comparatively create more harm than benefits, the patent applications can be denied. In this situation, we can apply the policy of a balancing test that necessitates vigilant examinations of the challenging social and economic issues at play in a given jurisdiction.

Moreover, the innovation of living things, the embedded advantage to humanity and the environment ought to be promoted. The precautionary principle to appraise the jeopardy of biotechnology 
research must be followed by implementing strict legal responsibility rules. In relation to this, an effectual mechanism at the global level can be established which will enable the challenge of life patents application before they are granted on the grounds of safeguarding public good and collective knowledge. Additionally, if multinational corporations (MNC) claim ownership over genetic technologies, they must also maintain the equilibrium between the protection and implementation of patent rights against universal human rights obligations. The State parties to the International Covenant on Economic, Social, and Cultural Rights are only responsible to respect human rights in their countries, but at the same time, the MNCs ought to be held accountable for enforcement of the right to health as well. Generally, contractual agreements settle on the patent owner and it becomes visible that the scientific community or non-profit organisations are recognised only as inventors, while the assignee institutions mostly control the commercial interests. So, the donor of the human gene should at least get some financial reimbursement. Now it is essential to find an acceptable proposition to benefit sharing. We should also consider the penalty for infringement of patent rights, as the costs of legal proceedings are disproportionally disseminated across countries. Introducing simple provisions on license and compulsory licensing cannot always ensure accessibility of medicines at an economical rate for the patients, because it depends on the states environment and countrywide strategy. Simultaneously, flexible licenses would not be a fruitful approach for life form inventors.

Therefore, it is necessary to conduct empirical researches on the repercussions of patents on genes over the interest of stakeholders in health care. Since it is not possible to shut bio-industrialisation, in this situation the most coherent position is to proceed with vigilance, so that the adjudicating agency must scrutinise circumspectly, different patent applications for human stem cell research. Until the creation of a newfangled mechanism within the realm of genetic engineering exists, we can modify our regulation and social policies in the light of contemporary evidence and minimise commercialisation of life science creations. The main target of innovation ought to be the provision of reasonably priced health care and medical treatment to patients and thus try to perform our international human rights commitments. 